\title{
Virucidal and antiviral activity of astodrimer sodium against SARS-CoV-2 in vitro
}

Jeremy Paull ( $\nabla$ jeremy.paull@starpharma.com )

Starpharma Pty Ltd https://orcid.org/0000-0002-9981-421X

Graham Heery

Starpharma Pty Ltd

Michael Bobardt

The Scripps Research Institute

Alex Castellarnau

Starpharma Pty Ltd

Carolyn Luscombe

Starpharma Pty Ltd

Jacinth Fairley

Starpharma Pty Ltd

Philippe Gallay

The Scripps Research Institute

\section{Research Article}

Keywords: Astodrimer, COVID-19, dendrimer, antiviral, SARS CoV 2, SPL7013

Posted Date: April 20th, 2021

DOI: https://doi.org/10.21203/rs.3.rs-440941/v1

License: (c) (i) This work is licensed under a Creative Commons Attribution 4.0 International License.

Read Full License

Version of Record: A version of this preprint was published at Antiviral Research on May 16th, 2021. See the published version at https://doi.org/10.1016/j.antiviral.2021.105089. 
1 Title: Virucidal and antiviral activity of astodrimer sodium against SARS-CoV-2 in vitro.

3 Authors: Jeremy R.A. Paull ${ }^{\mathrm{a}, *}$; Graham P. Heery ${ }^{\mathrm{a}}$, Michael D. Bobardt ${ }^{\mathrm{b}}$, Alex Castellarnau ${ }^{\mathrm{a}}$;

4 Carolyn A. Luscombe ${ }^{\mathrm{a}}$; Jacinth K. Fairley ${ }^{\mathrm{a}}$; Philippe A. Gallay ${ }^{\mathrm{b}}$

6 Author affiliations:

7 a Starpharma Pty Ltd, 4-6 Southampton Crescent, Abbotsford, Victoria 3067, Australia

$8 \quad \mathrm{~b}$ Department of Immunology and Microbiology, The Scripps Research Institute, La Jolla, CA 9 92307, USA

* Corresponding author: jeremy.paull@starpharma.com (JP)

\section{Declaration of interest:}

13 The authors declare the following financial interests that may be considered as potential

14 competing interests: J.R.A.P., J.K.F. and G.P.H. are paid employees of Starpharma Pty Ltd. A.C.

15 and C.A.L. are paid consultants to Starpharma Pty Ltd.

16

17 Word count:

18 Abstract: 284

19 Text: 3463

20 Inserts: 4 tables, 5 figures 
21 Abstract

22 An effective response to the ongoing coronavirus disease (COVID-19) pandemic caused by

23 severe acute respiratory syndrome coronavirus 2 (SARS-CoV-2) will involve a range of

24 complementary preventive modalities. The current studies were conducted to evaluate the in

25 vitro SARS-CoV-2 antiviral and virucidal activity of astodrimer sodium, a dendrimer with broad

26 spectrum antimicrobial activity, including against enveloped viruses in in vitro and in vivo

27 models, that is marketed for antiviral and antibacterial applications. We report that astodrimer

28 sodium inhibits replication of SARS-CoV-2 in Vero E6 and Calu-3 cells, with 50\% effective

29 concentrations $\left(\mathrm{EC}_{50}\right)$ for i) reducing virus-induced cytopathic effect of 0.002 to $0.012 \mathrm{mg} / \mathrm{mL}$ in

30 Vero E6 cells, and ii) infectious virus release by plaque assay of 0.019 to $0.032 \mathrm{mg} / \mathrm{mL}$ in Vero

31 E6 cells and 0.031 to $0.037 \mathrm{mg} / \mathrm{mL}$ in Calu-3 cells. The selectivity index (SI) in these assays was

32 as high as 2197. Astodrimer sodium was also virucidal, reducing SARS-CoV-2 infectivity by

$33>99.9 \%\left(>3 \log _{10}\right)$ within 1 minute of exposure, and up to $>99.999 \%\left(>5 \log _{10}\right)$ shown at

34 astodrimer sodium concentrations of 10 to $30 \mathrm{mg} / \mathrm{mL}$ in Vero E6 and Calu-3 cell lines.

35 Astodrimer sodium also inhibited infection in a primary human airway epithelial cell line. The

36 data were similar for all investigations and were consistent with the potent antiviral and virucidal

37 activity of astodrimer sodium being due to inhibition of virus-host cell interactions, as previously

38 demonstrated for other viruses. Further studies will confirm if astodrimer sodium binds to SARS-

39 CoV-2 spike protein and physically blocks initial attachment of the virus to the host cell. Given

40 the in vitro effectiveness and significantly high SI, astodrimer sodium warrants further

41 investigation for potential as a nasally administered or inhaled antiviral agent for SARS-CoV-2

42 prevention and treatment applications.

43 Keywords: Astodrimer; COVID-19; dendrimer; antiviral; SARS-CoV-2; SPL7013 


\section{1. Introduction}

46 The ongoing pandemic coronavirus disease 2019 (COVID-19), caused by severe acute

47 respiratory syndrome coronavirus-2 (SARS-CoV-2) infection, has resulted in unprecedented

48 efforts to rapidly develop strategies to contain infection rates for the protection of vulnerable

49 populations. An effective public health response to the current pandemic will involve currently

50 available vaccines being complemented by supplementary preventive modalities.

51 SARS-CoV-2 receptors and coreceptors have been shown to be highly expressed in nasal

52 epithelial cells (Sungnak et al., 2020). This finding is consistent with the virus infectivity or

53 replication pattern along the respiratory tract, which peaks proximally (nasal cavity) and is

54 relatively minimal in the distal alveolar regions (Hou et al., 2020). These findings suggest that

55 nasal carriage of the virus is a key feature of transmission, and that nasally administered

56 therapeutic modalities could be potentially effective in helping to prevent spread of infection.

57 Astodrimer sodium (SPL7013) is a generation-four lysine dendrimer with a polyanionic surface

58 charge (McCarthy et al., 2005) that is active against several enveloped and non-enveloped

59 viruses including human immunodeficiency virus-1 (HIV-1) (Lackman-Smith et al., 2008,

60 Tyssen et al., 2010), herpes simplex virus (HSV)-1 and -2 (Gong et al., 2005), H1N1 and H3N2

61 influenza virus, human respiratory syncytial virus (HRSV), human papillomavirus (HPV),

62 adenovirus and Zika virus (unpublished data). Astodrimer sodium also has antibacterial

63 properties. Both size and surface charge contribute to the function of the compound (Tyssen et

64 al., 2010), and when administered topically, astodrimer sodium is not absorbed systemically

65 (Chen et al., 2009; O’Loughlin et al., 2010; McGowan et al., 2011). 
66 Vaginally administered astodrimer sodium protected macaques from infection with chimeric

67 simian-HIV-1 (SHIV)89.6P (Jiang et al., 2005), and mice and guinea pigs from HSV-2 infection

68 (Bernstein et al., 2003) in vaginal infection challenge models. Astodrimer 1\% Gel (10 mg/mL

69 astodrimer sodium) administered vaginally has been shown to be safe and effective in phase 2

70 and large phase 3 trials for treatment and prevention of bacterial vaginosis (BV) (Chavoustie et

71 al., 2020; Waldbaum et al., 2020; Schwebke et al., 2021) and is marketed in Europe, Australia,

72 New Zealand and several countries in Asia.

73 The current studies were conducted to assess the antiviral and virucidal activity of astodrimer

74 sodium against SARS-CoV-2 in vitro, to determine its potential as a reformulated, nasally

75 administered or inhaled antiviral agent to help prevent spread of SARS-CoV-2 infection.

\section{2. Materials and methods}

$77 \quad 2.1$ Virus, cell culture, astodrimer sodium and controls

78 SARS-CoV-2 hCoV-19/Australia/VIC01/2020 was a gift from Melbourne's Peter Doherty

79 Institute for Infection and Immunity (Melbourne, Australia). Virus stock was generated at

80 360Biolabs (Melbourne, Australia) by two passages in Vero cells in virus growth media, which

81 comprised Minimal Essential Medium (MEM) without L-glutamine supplemented with 1\% (w/v)

82 L-glutamine, $1.0 \mu \mathrm{g} / \mathrm{mL}$ of L-(tosylamido-2-phenyl) ethyl chloromethyl ketone (TPCK)-treated

83 trypsin (Worthington Biochemical, NJ, USA), 0.2\% bovine serum albumin (BSA) and 1\%

84 insulin-transferrin-selenium (ITS).

85 SARS-CoV-2 2019-nCoV/USA-WA1/2020 strain was isolated from an oropharyngeal swab

86 from a patient with a respiratory illness who developed clinical disease (COVID-19) in January

872020 in Washington, US, and sourced from BEI Resources (NR-52281). Virus was derived from 
88 African green monkey kidney Vero E6 cells or lung homogenates from human angiotensin

89 converting enzyme 2 (hACE2) transgenic mice.

90 Vero E6 and human Calu-3 cell lines were cultured in MEM without L-glutamine supplemented 91 with 10\% (v/v) heat-inactivated fetal bovine serum (FBS) and 1\% (w/v) L-glutamine. Vero E6

92 and Calu-3 cells were passaged for a maximum of 10 passages for antiviral and virucidal studies.

93 Hank's balanced salt solution (HBSS) with 2\% FBS was used for infection. The 2019-

$94 \mathrm{nCoV/USA}-\mathrm{WA} 1 / 2020$ strain antiviral assays were performed with a multiplicity of infection 95 (MOI) of 0.1.

96 The virus inoculums for virucidal assays were $10^{4}, 10^{5}$, and $10^{6} \mathrm{pfu} / \mathrm{mL}$. After defined incubation 97 periods, the solution was pelleted through a 20\% sucrose cushion (Beckman SW40 Ti rotor) and 98 resuspended in $1.5 \mathrm{~mL}$ MEM, which was then added to $2.5 \times 10^{4}$ cells/well.

99 Primary human bronchial epithelial cells (HBEpC) (Sigma-Aldrich, MO, USA) were grown and 100 maintained in HBEpC/HTEpC growth medium (Cell Applications, CA, USA). These primary 101 cells express the ACE2 receptor and are permissive to SARS-CoV-2 infection. These cells were 102 used to determine the antiviral effect of astodrimer sodium against SARS-CoV-2 in a primary 103 human airway epithelial cell line. Cells were infected with SARS-CoV-2 2019-nCoV/USA$104 \mathrm{WA} 1 / 2020$ at $10^{3} \mathrm{pfu} / \mathrm{mL}$ with $1 \mathrm{~mL}$ added to $2.5 \times 10^{4}$ cells $/$ well. The positive control was 105 addition of $10 \mu \mathrm{g} / \mathrm{mL}$ of SARS-CoV-2 spike protein antibody (pAb, T01KHuRb) 106 (ThermoFisher, MA, USA) at the time of infection.

107 Astodrimer sodium was prepared as $100 \mathrm{mg} / \mathrm{mL}$ in water and stored at $4^{\circ} \mathrm{C}$. Astodrimer sodium 108 has a molecular weight of $16581.57 \mathrm{~g} / \mathrm{mol}$ and the structure is described and illustrated in Tyssen 
109 et al., 2010. The purity of the compound used in these studies was assessed by ultra-high-

110 performance liquid chromatography (UPLC) to be $98.79 \%$.

111 Remdesivir (MedChemExpress, NJ, USA) was used as a positive control in the virus-induced

112 cytopathic effect (CPE) inhibition and plaque assays.

113 Iota-carrageenan (Sigma-Aldrich, MO, USA) was used in the primary epithelial cell

114 nucleocapsid and plaque assays to compare the antiviral activity of this substance with

115 astodrimer sodium. Concentrations used are those reported to show activity against SARS-CoV-

1162 (Bansal et al., 2020).

2.2 Virus-induced cytopathic effect inhibition assay

118 Vero E6 (ATCC-CRL1586) cell stocks were generated in cell growth medium, which

119 comprised MEM without L-glutamine supplemented with 10\% (v/v) heat-inactivated FBS and

$1201 \%(\mathrm{w} / \mathrm{v})$ L-glutamine. Vero E6 cell monolayers were seeded in 96-well plates at

$1212 \times 10^{4}$ cells/well in $100 \mu \mathrm{L}$ growth medium (MEM supplemented with $1 \%(\mathrm{w} / \mathrm{v})$ L-glutamine,

$1222 \% \mathrm{FBS}$ ) and incubated overnight at $37^{\circ} \mathrm{C}$ in $5 \% \mathrm{CO}_{2} . \mathrm{SARS}-\mathrm{CoV}-2$ infection was established

123 by using an MOI of 0.05 to infect cell monolayers.

124 Astodrimer sodium or remdesivir were serially diluted 1:3, 9 times and each compound

125 concentration was assessed for both antiviral efficacy and cytotoxicity in triplicate.

126 Astodrimer sodium was added to Vero E6 cells 1 hour prior to infection or 1 hour post-

127 infection with SARS-CoV-2. Cell cultures were incubated at $37^{\circ} \mathrm{C}$ in $5 \% \mathrm{CO}_{2}$ for 4 days prior

128 to assessment of CPE. The virus growth media was MEM supplemented with 1\% (w/v) L-

129 glutamine, 2\% FBS, and $4 \mu \mathrm{g} / \mathrm{mL}$ TPCK-treated trypsin. On Day 4, viral-induced CPE and

130 cytotoxicity of the compound were determined by measuring the viable cells using the 
131 methylthiazolyldiphenyl-tetrazolium bromide (MTT) assay (MP Biomedicals, NSW,

132 Australia). Absorbance was measured at $540-650 \mathrm{~nm}$ on a plate reader.

\subsection{Antiviral plaque assay evaluation and nucleocapsid ELISA}

134 For the antiviral evaluation, astodrimer sodium was added to cells 1 hour prior to, at the time of, 135 and 1 hour after exposing the cells to virus. For both the antiviral and virucidal assays, at 6 hours 136 after infection, cells were washed to remove astodrimer sodium and/or any virus remaining in the 137 supernatant, in such way that a

138 Following initial infection, cell cultures were incubated and supernatants recovered after 16 139 hours or 4 days. The amount of virus in the supernatants was determined by plaque assay (plaque 140 forming unit [pfu]) and by nucleocapsid enzyme-linked immunosorbent assay (ELISA). The

141 plaque assay used was as described in van den Worm et al., 2012, utilizing 2\% sodium

142 carboxymethyl cellulose overlay, fixation of cells by $4 \%$ paraformaldehyde and staining with $1430.1 \%$ crystal violet. The nucleocapsid ELISA assay was as described by Bioss Antibodies, USA 144 (BSKV0001).

145 The assessment of astodrimer sodium cytotoxicity occurred on Day 4 by measuring lactate 146 dehydrogenase (LDH) activity in the cytoplasm using an LDH detection kit (Cayman Chemical), 147 with $0.5 \%$ saponin used as the positive cytotoxic control.

\subsection{Virucidal assay}

149 For the virucidal evaluation, concentrations of astodrimer sodium $(0.0046$ to $30 \mathrm{mg} / \mathrm{mL})$ were 150 incubated with SARS-CoV-2 2019-nCoV/USA-WA1/2020 for times ranging from 5 seconds to 1512 hours. To neutralize the effect of astodrimer sodium, unbound compound was separated from 152 the astodrimer:virus mixture by pelleting the preincubated mixture through a $20 \%$ sucrose 153 cushion (Beckman SW40 Ti rotor). The astodrimer sodium-containing supernatant was removed 
154 (i.e., neutralising the effect of SPL7013) and then the pelleted virus was gently resuspended and

155 added to Vero E6 or Calu-3 cell cultures. Virus infection, cell culture and cytotoxicity

156 assessment was as described for the plaque assay described in Section 2.3.

157 All antiviral and virucidal assays were performed in triplicate, except where indicated in the 158 results.

\subsection{Determination of $50 \%$ effective concentration $\left(\mathrm{EC}_{50}\right)$ and cytotoxicity $\left(\mathrm{CC}_{50}\right)$}

160 The concentration of compound that gives a 50\% reduction in viral-induced CPE, infectious

161 virus (pfu/mL), or secreted viral nucleocapsid (EC50) was calculated using the formula of

162 Pauwels et al., 1998.

163 The concentration of compound that resulted in a $50 \%$ reduction in cell viability $\left(\mathrm{CC}_{50}\right)$ after

1644 days of culture was also calculated by the formula of Pauwels et al., 1998.

\subsection{Primary Epithelial Cell Assay}

166 Astodrimer sodium $(0,1.1,3.3$ and $10 \mathrm{mg} / \mathrm{mL})$ or iota-carrageenan $(0,6,60$ and $600 \mu \mathrm{g} / \mathrm{mL})$

167 were added to HBEpC cells 1 hour prior to infection with SARS-CoV-2. Cells were cultured for

1684 days post-infection and the cell supernatant was analysed for the amount of secreted SARS-

169 CoV-2 nucleocapsid by ELISA, and infectious virus was quantitated by plaque assay, as 170 described in Section 2.3.

\section{3. Results}

\subsection{Virus-induced cytopathic effect inhibition}

173 In two independent virus-induced CPE inhibition assays, astodrimer sodium inhibited SARS-

174 CoV-2 (hCoV-19/Australia/VIC01/2020) replication in Vero E6 cells in a dose dependent 
175 manner (Table 1). Astodrimer sodium inhibited viral replication when added either 1 hour prior

176 to infection, or 1 hour post-infection with SARS-CoV-2.

177 Astodrimer sodium was initially tested in the range of 0.0013 to $8.63 \mathrm{mg} / \mathrm{mL}$. In the repeat set of

178 assays, astodrimer sodium was tested in the range of 0.0001 to $0.86 \mathrm{mg} / \mathrm{mL}$ to help further

179 characterize the lower end of the dose response curve. The effective and cytotoxic

180 concentrations, and selectivity indices from the assays are shown individually and as means in

181 Table 1 for CPE determined readouts.

182 The selectivity index (SI) for astodrimer sodium against SARS-CoV-2 in the CPE studies ranged

183 from 793 to 2197 for the initial assays where compound was added 1 hour prior to infection and

1841 hour after infection, respectively, and was $>70$ to $>80$ in the repeat assays, in which

185 cytotoxicity was not observed up to the highest concentration tested $(0.86 \mathrm{mg} / \mathrm{mL})$.

186 The positive control, remdesivir, was also active in the CPE inhibition assay, with a SI of $>33$.

\subsection{Antiviral efficacy}

188 To determine the ability of astodrimer sodium to inhibit globally diverse SARS-CoV-2 strains, 189 the compound was evaluated against the 2019-nCoV/USA-WA1/2020 virus in Vero E6 cells and 190 human Calu-3 cells. Antiviral readouts were based on virological endpoints of infectious virus or 191 viral nucleocapsid released into the supernatant post-infection. As shown in Table 2 and Figures 1921 and 2, astodrimer inhibited the 2019-nCoV/USA-WA1/2020 strain with an EC 500.019 to 0.032 $193 \mathrm{mg} / \mathrm{mL}$ and 0.031 to $0.037 \mathrm{mg} / \mathrm{mL}$ for infectious virus release as determined by plaque assay in 194 Vero E6 cell for Calu-3 cells, respectively. These data are consistent with the inhibition by 195 astodrimer of the replication of the Australian SARS-CoV-2 isolate in vitro. The dose response 196 data for the nucleocapsid released into the supernatant by ELISA were similar to the infectious 
197 virus release data in each cell line (data not shown). The positive control, remdesivir, was also

198 active in the plaque assay.

\subsection{Virucidal efficacy}

200 Virucidal assays investigated if astodrimer sodium could reduce viral infectivity by irreversibly 201 inactivating SARS-CoV-2 prior to infection of Vero E6 cells and human airway Calu-3 cells.

202 Following incubation of virus with astodrimer for up to 2 hours and neutralization of astodrimer, 203 the astodrimer-exposed virus was added to cell cultures. After either 16 hours or 96 hours (Day

204 4), the cell culture supernatant was collected for assessment of progeny viral infectivity as 205 determined by the amount of secreted infectious virus and nucleocapsid. The SARS-CoV-2 206 replication lifecycle is completed in approximately 8 hours (Ogando et al., 2020) and in these 207 studies, we sampled at 16 hours (2 lifecycles) or Day 4 (12 lifecycles) post-infection.

208 Enabling a possible 12 rounds of infection, the Day 4 (96 hour) sampling time point identified 209 that exposure of $10^{6} \mathrm{pfu} / \mathrm{mL}$ SARS-CoV-2 to astodrimer sodium for 1 to 2 hours resulted in a 210 dose-dependent reduction in viral infectivity, with 10 to $30 \mathrm{mg} / \mathrm{mL}$ astodrimer sodium achieving 211 up to $>99.999 \%\left(>5 \log _{10}\right)$ reduced infectivity in Vero E6 cells and $>99.9 \%\left(>3 \log _{10}\right)$ reduced

212 infectivity in Calu-3 cells (data not shown) compared to untreated virus. SARS-CoV-2

213 infectivity was also reduced by up to $>99.999 \%$ in Vero E6 cells when the incubation time of

214 astodrimer (10 to $30 \mathrm{mg} / \mathrm{mL}$ ) with $10^{6} \mathrm{pfu} / \mathrm{mL}$ virus was reduced to 15 to 30 minutes (data not 215 shown).

216 Incubation of astodrimer sodium with viral inoculums of $10^{4}, 10^{5}$ and $10^{6} \mathrm{pfu} / \mathrm{mL}$ for as little as 2175 seconds resulted in evidence of reduced infectivity, with 10 to 15 minutes exposure being 218 sufficient to achieve $>99.9 \%$ reduction in virus infectivity, and greater reduction achieved with 
219 lower viral inoculum (>99.999\%, $10^{4} \mathrm{pfu} / \mathrm{mL}$ viral inoculum, 10 to $30 \mathrm{mg} / \mathrm{mL}$ astodrimer

220 sodium, and 10 to 15 min incubation time) (Table 3, Figure 3).

221 When assessed 16 hours post-infection of cells with astodrimer-exposed virus, it was found that

$222 \geq 10 \mathrm{mg} / \mathrm{mL}$ astodrimer sodium inactivated $>99.9 \%$ SARS-CoV-2 $\left(10^{4} \mathrm{pfu} / \mathrm{mL}\right)$ within as little as

2231 minute of exposure (Table 4, Figure 4).

\subsection{Antiviral Efficacy in Primary Human Airway Epithelial Cells}

225 To determine the ability of astodrimer sodium to prevent SARS-CoV-2 infection of primary

226 human epithelial cells, the compound was evaluated against the 2019-nCoV/USA-WA1/2020

227 strain in HBEpC cell culture. Astodrimer sodium was found to reduce infection of HBEpC

228 primary cells by SARS-CoV-2 by up to $98 \%$ vs virus control by nucleocapsid ELISA (Figure

$2295 \mathrm{~A}$ ), and by up to $95 \%$ in the plaque assay (data not shown). In contrast, treatment with iota230 carrageenan had minimal antiviral effect against SARS-CoV-2 in this cell line, with the highest

231 concentration tested reducing infection by just 17\% by nucleocapsid ELISA (Figure 5B), and just

$23221 \%$ in the plaque assay (data not shown). The maximum level of inhibition with astodrimer

233 sodium was comparable to inhibition achieved with the SARS-CoV-2 spike protein antibody

234 (pAb, T01KHuRb) positive control (see Figure 5A and B).

\section{4. Discussion}

236 Astodrimer sodium demonstrated potent antiviral activity against globally diverse SARS-CoV-2

237 strains in vitro. Antiviral activity was demonstrated by reduction in CPE, release of infectious

238 virus and release of viral nucleocapsid protein. Antiviral activity was demonstrated when

239 astodrimer sodium was added to cells prior to infection of cells and when the compound was 
240 added to cells already exposed to SARS-CoV-2. Irreversible virucidal activity was demonstrated

241 when astodrimer sodium was mixed with virus for as little as 1 minute.

242 Of note is a significantly high SI for astodrimer sodium in the antiviral assays relative to other

243 antiviral compounds under investigation for SARS-CoV-2 activity (Pizzorno et al., 2020).

244 Remdesivir was used as the antiviral positive control for the CPE inhibition and antiviral assays

245 and the experimental $\mathrm{EC}_{50}$ was consistent with published data generated with a different clinical

246 isolate of SARS-CoV-2 (Wang et al., 2020).

247 Astodrimer sodium inhibited infection of a human airway primary epithelial cell by SARS-CoV-

248 2, whereas iota-carrageenan, which is a polyanionic compound in marketed nasal spray

249 formulations, failed to provide significant inhibition at concentrations that have previously been

250 shown to reduce SARS-CoV-2 infection in Vero E6 cells (Bansal et al., 2020). The unique

251 structure of astodrimer sodium, a sulphonated, roughly spherical molecule with a core and

252 densely packed branches radiating out from the core, appears to provide potential benefits over

253 other polyanionic compounds such as iota-carrageenan and heparin, which are linear sulphated

254 molecules with a distribution of molecular weight. The authors are not aware of data showing

255 that iota-carrageenan is virucidal, while heparin has demonstrated a lack of irreversible, virucidal

256 interaction with HSV virion components (Ghosh et al., 2009).

257 The antiviral data are consistent with astodrimer sodium being a potent inhibitor of early events

258 in the virus lifecycle. The virucidal assay data suggest that astodrimer sodium antiviral activity

259 was consistent with the proposed mechanism of action of binding to virus, thereby irreversibly

260 inactivating virus and blocking infection. 
261 The virucidal activity of astodrimer sodium demonstrated that it irreversibly inhibits the early

262 phase of virus infection and replication. These findings suggest potent inhibition of viral

263 attachment, fusion and entry of the virus, which prevents virus replication and release of

264 infectious virus progeny.

265 Astodrimer sodium has been previously found to be an effective antiviral that exerts its inhibition

266 in the early virus-host receptor recognition interactions (Tyssen et al., 2010; Telwatte et al.,

267 2011), and its potential mechanism of action against SARS-CoV-2 is likely similar to that

268 identified for other pathogens. Astodrimer sodium was found to bind to HIV-1 by strong

269 electrostatic forces to positively charged clusters of highly conserved amino acids on HIV-1

270 gp120 protein and/or positively charged amino acid regions located between the stems of V1/V2

271 and V3 loops, which are exposed by conformational changes to gp120 after viral binding to the

272 receptor/co-receptor complex (Tyssen et al., 2010; Connell and Lortat-Jacob, 2013).

273 Many viruses utilize negatively charged heparan sulfate proteoglycans (HS) on the cell plasma

274 membrane as an initial means to scan the surface of the cell, and to attach in order to chaperone

275 the virus onto the receptor complex prior to viral entry (Sarrazin et al., 2011; Connell and Lortat-

276 Jacob, 2013). The receptor interactions occur in a sequential manner with virus-HS interactions

277 preceding receptor/co-receptor binding, which combined leads to fusion of the viral envelope

278 and the cell membrane.

279 Data indicate that astodrimer sodium-gp120 interaction may physically block initial HIV-1

280 association with HS and thereby block the subsequent virus-receptor complex functions.

281 Virucidal studies of astodrimer sodium determined that it did not disrupt the HIV-1 particle or

282 cause the loss of gp120 spike protein from the viral surface (Telwatte et al., 2011). 
283 A report by Liu et al., 2020, described that densely glycosylated trimeric SARS-CoV-2 spike (S)

284 protein subunit S1, which is important for receptor binding, binds to HS. To engage with the

285 ACE2 receptor, the S protein undergoes a hinge-like conformational change that transiently

286 hides or exposes the determinants of receptor binding (Wrapp et al., 2020). Recent studies have

287 identified the binding of heparin to the receptor binding domain (RBD) of S1 resulting in a

288 conformational change to the S protein (Mycroft-West et al., 2020a, b and c). Mutations in the S

289 protein that are distal from the RBD also impact on viral transmission (Walls et al., 2020; Korber

290 et al., 2020; Yuan et al., 2020). Non-RBD polybasic cleavage sites, including S1/S2 loop

291 (Hoffmann et al., 2020a), have been described on SARS-CoV-2 S protein (Qiao and Olvera de la

292 Cruz, 2020) and may also be a site of potential interaction with astodrimer sodium.

293 SARS-CoV-2 utilizes the ACE2 receptor for viral infection of host cells (Hoffmann et al.,

294 2020b). Human CoV-NL63 also utilizes HS and ACE2 as its cellular receptor complex

295 (Milewska et al., 2014). The importance of HS for viral infectivity was also demonstrated for

296 close genetically related pseudo-typed SARS-CoV (Lang et al., 2011). The potential dependence

297 of SARS-CoV-2 on HS for attachment and entry combined with antiviral data from other viruses

298 suggest that negatively charged astodrimer sodium may have antiviral activity against SARS-

299 CoV-2 in vitro by blocking the early virus-receptor recognition events.

300 Astodrimer sodium is a polyanionic dendrimer reformulated for use as a topical, nasally

301 administered antiviral agent to inactivate SARS-CoV-2 before infection can occur. The potential

302 advantages of astodrimer sodium over other technologies include its lack of systemic absorption

303 following topical application (Chen et al., 2009; O'Loughlin et al., 2010; McGowan et al., 2011).

304 In addition, the SI of astodrimer sodium for SARS-CoV-2 is high and in a vaginal gel

305 formulation $(10 \mathrm{mg} / \mathrm{mL})$, the compound has been shown to be safe and effective in phase 2 and 
306 large phase 3 trials for treatment and prevention of BV (Chavoustie et al., 2020; Waldbaum et

307 al., 2020; Schwebke et al., 2021) and is now marketed in Europe, Australia, New Zealand and

308 several countries in Asia. Astodrimer sodium is also the active antiviral substance in VivaGel ${ }^{\circledR}$

309 condom products that have marketing authorization in Europe, Japan, Australia/New Zealand

310 and Canada. However, these current formulations are not appropriate for use to protect the

311 respiratory tract from SARS-CoV-2 infection.

\section{5. Conclusions}

313 Data from the current studies, taken together with studies of astodrimer sodium antiviral activity

314 against HIV-1, and HSV-1 and -2, indicate that the compound exerts its antiviral activity against 315 geographically diverse SARS-CoV-2 isolates by interfering with the early virus-cell recognition

316 events. Astodrimer sodium is a potent virucidal agent that reduces the infectivity of SARS-CoV-

3172 by $>99.9 \%$ after 1 minute of exposure to the virus. These studies support astodrimer sodium

318 being able to prevent early virus entry steps such as attachment, thereby reducing or preventing

319 viral infection or cell-cell spread.

320 An antiviral agent such as astodrimer sodium that blocks binding of the virus to target cells could

321 potentially be used as a preventive and/or a therapeutic agent against SARS-CoV-2. These

322 antiviral studies suggest that reformulation of astodrimer sodium for delivery to the respiratory

323 tract may be an effective preventive strategy to block SARS-CoV-2 transmission and augment

324 other protective and therapeutic strategies.

325 The potent antiviral and virucidal activity of astodrimer sodium against SARS-CoV-2 warrants

326 further investigation. 


\section{Tables}

Table 1: Antiviral efficacy, measured by a reduction in CPE in virus-infected cells at Day 4 post-infection, and selectivity of astodrimer sodium against SARS-CoV-2 (hCoV-19/Australia/VIC01/2020) infection of Vero E6 cells

\begin{tabular}{|c|c|c|c|c|}
\hline Compound / Assay Type & Repeat & $\mathrm{EC}_{50}(\mathrm{mg} / \mathrm{mL})$ & $\mathrm{CC}_{50}(\mathrm{mg} / \mathrm{mL})$ & SI \\
\hline \multirow{3}{*}{$\begin{array}{l}\text { Astodrimer sodium added } \\
\text { 1-hour pre-infection }\end{array}$} & Assay 1 & 0.004 & 2.93 & 793 \\
\hline & Assay 2 & 0.012 & $>0.863$ & $>70$ \\
\hline & Mean \pm SD & $0.008 \pm 0.006$ & $\mathrm{NC}$ & $>431^{\mathrm{a}}$ \\
\hline \multirow{3}{*}{$\begin{array}{l}\text { Astodrimer sodium added } \\
\text { 1-hour post-infection }\end{array}$} & Assay 1 & 0.002 & 3.29 & 2197 \\
\hline & Assay 2 & 0.011 & $>0.863$ & $>80$ \\
\hline & Mean \pm SD & $0.006 \pm 0.007$ & $\mathrm{NC}$ & $>1138^{\mathrm{a}}$ \\
\hline \multirow{2}{*}{$\begin{array}{l}\text { Remdesivir added 1-hour } \\
\text { post-infection }\end{array}$} & Assay 1 & $0.59 \mu \mathrm{M}$ & $>20 \mu \mathrm{M}$ & $>33$ \\
\hline & Assay 2 & $0.61 \mu \mathrm{M}$ & $>20 \mu \mathrm{M}$ & $>33$ \\
\hline
\end{tabular}

${ }^{a}$ Average of Assay 1 and Assay 2 SI 
Table 2: Antiviral efficacy, measured by a reduction in mean infectious virus $\left(\log _{10} \mathrm{pfu} / \mathrm{mL}\right)$, and selectivity of astodrimer

sodium against SARS-CoV-2 (2019-nCoV/USA-WA1/2020) on Day 4 post-infection

\begin{tabular}{|c|c|c|c|c|}
\hline Compound / Assay Type & Cell Line & $\mathrm{EC}_{50}(\mathrm{mg} / \mathrm{mL})$ & $\mathrm{CC}_{50}(\mathrm{mg} / \mathrm{mL})$ & SI \\
\hline \multirow{2}{*}{$\begin{array}{l}\text { Astodrimer sodium added } \\
\text { 1-hour pre-infection }\end{array}$} & Vero E6 & 0.032 & 15.09 & 472 \\
\hline & Calu-3 & 0.037 & 21.76 & 588 \\
\hline \multirow{2}{*}{$\begin{array}{l}\text { Astodrimer sodium added } \\
\text { at time of infection }\end{array}$} & Vero E6 & 0.020 & 15.09 & 755 \\
\hline & Calu-3 & 0.035 & 21.76 & 622 \\
\hline \multirow{2}{*}{$\begin{array}{l}\text { Astodrimer sodium added } \\
\text { 1-hour post-infection }\end{array}$} & Vero E6 & 0.019 & 15.09 & 794 \\
\hline & Calu-3 & 0.030 & 21.76 & 725 \\
\hline \multirow{2}{*}{$\begin{array}{l}\text { Remdesivir added 1-hour } \\
\text { post-infection }\end{array}$} & Vero E6 & $0.791 \mu \mathrm{M}$ & $\mathrm{N} / \mathrm{A}$ & $\mathrm{N} / \mathrm{A}$ \\
\hline & Calu-3 & $0.589 \mu \mathrm{M}$ & N/A & $\mathrm{N} / \mathrm{A}$ \\
\hline
\end{tabular}


Table 3: Virucidal efficacy of $10 \mathrm{mg} / \mathrm{mL}$ astodrimer sodium against SARS-CoV-2 (2019-nCoV/USA-WA1/2020), measured by

350 a reduction in mean infectious virus $\left(\log _{10} \mathrm{pfu} / \mathrm{mL}\right)$, at 96 hours post-infection

\begin{tabular}{|c|c|c|c|}
\hline $\begin{array}{l}\text { Viral Load } \\
(\text { pfu/mL })\end{array}$ & $\begin{array}{l}\text { Virus:Astodrimer } \\
\text { Incubation Time }\end{array}$ & $\begin{array}{l}\text { Reduction vs. Virus Control } \\
\left(\log _{10} \pm \text { SD) }\right.\end{array}$ & $\begin{array}{c}\text { Reduction vs. Virus Control } \\
(\%)\end{array}$ \\
\hline \multirow{6}{*}{$10^{6}$} & $5 \mathrm{sec}$ & $0.10 \pm 0.20$ & 20.567 \\
\hline & $10 \mathrm{sec}$ & $0.03 \pm 0.06$ & 7.388 \\
\hline & $30 \mathrm{sec}$ & $0.10 \pm 0.10$ & 20.567 \\
\hline & $1 \mathrm{~min}$ & $0.33 \pm 0.12$ & 53.584 \\
\hline & $10 \mathrm{~min}$ & $2.20 \pm 0.10$ & 99.369 \\
\hline & $15 \mathrm{~min}$ & $3.67 \pm 0.23$ & 99.979 \\
\hline \multirow{6}{*}{$10^{5}$} & $5 \mathrm{sec}$ & $0.33 \pm 0.21$ & 53.584 \\
\hline & $10 \mathrm{sec}$ & $0.23 \pm 0.06$ & 41.566 \\
\hline & $30 \mathrm{sec}$ & $0.30 \pm 0.17$ & 49.881 \\
\hline & $1 \mathrm{~min}$ & $0.47 \pm 0.21$ & 65.855 \\
\hline & $10 \mathrm{~min}$ & $3.70 \pm 0.26$ & 99.980 \\
\hline & $15 \mathrm{~min}$ & $4.60 \pm 0.10$ & 99.998 \\
\hline \multirow{6}{*}{$10^{4}$} & $5 \mathrm{sec}$ & $-0.13 \pm 0.21$ & -35.936 \\
\hline & $10 \mathrm{sec}$ & $0.07 \pm 0.29$ & 14.230 \\
\hline & $30 \mathrm{sec}$ & $0.10 \pm 0.10$ & 20.567 \\
\hline & $1 \mathrm{~min}$ & $0.10 \pm 0.00$ & 20.567 \\
\hline & $10 \mathrm{~min}$ & $5.07 \pm 0.25$ & $>99.999$ \\
\hline & $15 \mathrm{~min}$ & $5.83 \pm 0.12$ & $>99.999$ \\
\hline
\end{tabular}


Table 4: Virucidal efficacy of $10 \mathrm{mg} / \mathrm{mL}$ astodrimer sodium against SARS-CoV-2 (2019-nCoV/USA-WA1/2020), measured by

a reduction in mean infectious virus $\left(\log _{10} \mathrm{pfu} / \mathrm{mL}\right)$, at 16 hours post-infection

\begin{tabular}{|cccc|}
\hline Viral Load (pfu/mL) & $\begin{array}{c}\text { Virus:Astodrimer } \\
\text { Incubation Time }\end{array}$ & $\begin{array}{c}\text { Reduction vs. Virus Control } \\
\left(\log _{\mathbf{1 0}} \pm \text { SD) }\right.\end{array}$ & $\begin{array}{c}\text { Reduction vs. Virus Control } \\
(\%)\end{array}$ \\
\hline \multirow{3}{*}{$10^{5}$} & $30 \mathrm{sec}$ & $0.00 \pm 0.36$ & 0.000 \\
& $1 \mathrm{~min}$ & $2.63 \pm 0.15$ & 99.767 \\
& $5 \mathrm{~min}$ & $4.63 \pm 0.31$ & 99.998 \\
\hline $15 \mathrm{~min}$ & $4.60 \pm 0.10$ & 99.998 \\
\hline \multirow{2}{*}{$10^{4}$} & $30 \mathrm{sec}$ & $0.20 \pm 0.20$ & 99.904 \\
& $1 \mathrm{~min}$ & $3.17 \pm 0.12$ & 99.979 \\
& $5 \mathrm{~min}$ & $3.67 \pm 0.21$ & 99.990 \\
\hline
\end{tabular}




\section{Figure Captions}

364 Figure 1. Dose-response and cytotoxicity analysis of SARS-CoV-2 (2019-nCoV/USA-

365 WA1/2020) antiviral activity of astodrimer sodium in Vero E6 cells as measured by 366 infectious virus release $\left(\log _{10} \mathrm{pfu} / \mathrm{mL}\right)$ on Day 4 post-infection

367 Astodrimer sodium $(0.0005$ to $10 \mathrm{mg} / \mathrm{mL})$ was added to cell cultures 1 hour prior to $(\mathrm{t}=-1 \mathrm{~h})$, at 368 the time of $(t=0)$, and 1 hour post-infection $(t=+1 h)$. Cytotoxicity was assessed by LDH 369 detection (OD @ $490 \mathrm{~nm}$ ), with $0.5 \%$ saponin used as the positive cytotoxic control. Points and 370 error bars represent mean \pm SD of triplicate readings.

371 Figure 2. Dose-response and cytotoxicity analysis of SARS-CoV-2 (2019-nCoV/USA-

372 WA1/2020) antiviral activity of astodrimer sodium in Calu-3 cells as measured by

373 infectious virus release $\left(\log _{10} \mathrm{pfu} / \mathrm{mL}\right)$ on Day 4 post-infection

374 Astodrimer sodium $(0.0005$ to $10 \mathrm{mg} / \mathrm{mL})$ was added to cell cultures 1 hour prior to $(\mathrm{t}=-1 \mathrm{~h})$, at 375 the time of $(t=0)$, and 1 hour post-infection $(t=+1 h)$. Cytotoxicity was assessed by LDH 376 detection (OD @ $490 \mathrm{~nm}$ ), with $0.5 \%$ saponin used as the positive cytotoxic control. Points and 377 error bars represent mean \pm SD of triplicate readings.

378 Figure 3. Virucidal efficacy of astodrimer sodium against SARS-CoV-2 (2019-nCoV/USA379 WA1/2020) measured by a reduction in mean infectious virus $\left(\log _{10} \mathrm{pfu} / \mathrm{mL}\right)$, at 96 hours 380 post-infection in Vero E6 cells

381 Astodrimer sodium (1 to $30 \mathrm{mg} / \mathrm{mL}$ ) was incubated with SARS-CoV-2 (2019-nCoV/USA-

382 WA1/2020) for $5 \mathrm{sec}$ up to $15 \mathrm{~min}$. Treated virus was added to Vero E6 cells and the amount of 383 infectious virus in the supernatant was determined by plaque assay 96 hours post-infection. 
384 Graph shows dose-response of astodrimer sodium virucidal activity using $10^{4} \mathrm{pfu} / \mathrm{mL}$ virus

385 inoculum. Points and error bars represent mean \pm SD of triplicate readings. Dotted line indicates

386 level of mean infectious virus when untreated virus was added to Vero E6 cells (virus control).

387 Figure 4. Virucidal efficacy of astodrimer sodium against SARS-CoV-2 (2019-nCoV/USA-

388 WA1/2020) measured by a reduction in mean infectious virus $\left(\log _{10} \mathrm{pfu} / \mathrm{mL}\right)$, at 16 hours

389 post-infection in Vero E6 cells

390 Astodrimer sodium (0.0046 to $30 \mathrm{mg} / \mathrm{mL})$ was incubated with SARS-CoV-2 (2019-nCoV/USA-

391 WA1/2020) for $30 \mathrm{sec}, 1 \mathrm{~min}, 5 \mathrm{~min}$ and $15 \mathrm{~min}$. Treated virus was added to Vero E6 cells and

392 the amount of infectious virus in the supernatant was determined by plaque assay 16 hours post-

393 infection. Graph shows dose-response of astodrimer sodium virucidal activity using $10^{4} \mathrm{pfu} / \mathrm{mL}$

394 virus inoculum. Points and error bars represent mean \pm SD of triplicate readings. Dotted line

395 indicates level of mean infectious virus when untreated virus was added to Vero E6 cells (virus

396 control).

397 Figure 5. Antiviral efficacy of astodrimer sodium and iota-carrageenan against SARS-

398 CoV-2 (2019-nCoV/USA-WA1/2020) measured by a reduction in nucleocapsid (ng/mL), at

399 Day 4 post-infection in human bronchial epithelial primary cells (HBEpC)

400 Astodrimer sodium $(0,1.1,3.3$ and $10 \mathrm{mg} / \mathrm{mL})$ or iota-carrageenan $(0,6,60$ and $600 \mu \mathrm{g} / \mathrm{mL})$

401 were added to cell cultures 1 hour prior to infection.

402 A. Dose-response of astodrimer sodium antiviral activity. Points and error bars represent mean \pm

403 SD of triplicate readings.

404 B. Dose-response of carrageenan antiviral activity. Points represent one replicate.

405 Dotted lines indicates level of inhibition achieved with positive control, SARS-CoV-2 pAb. 
Fig. 1

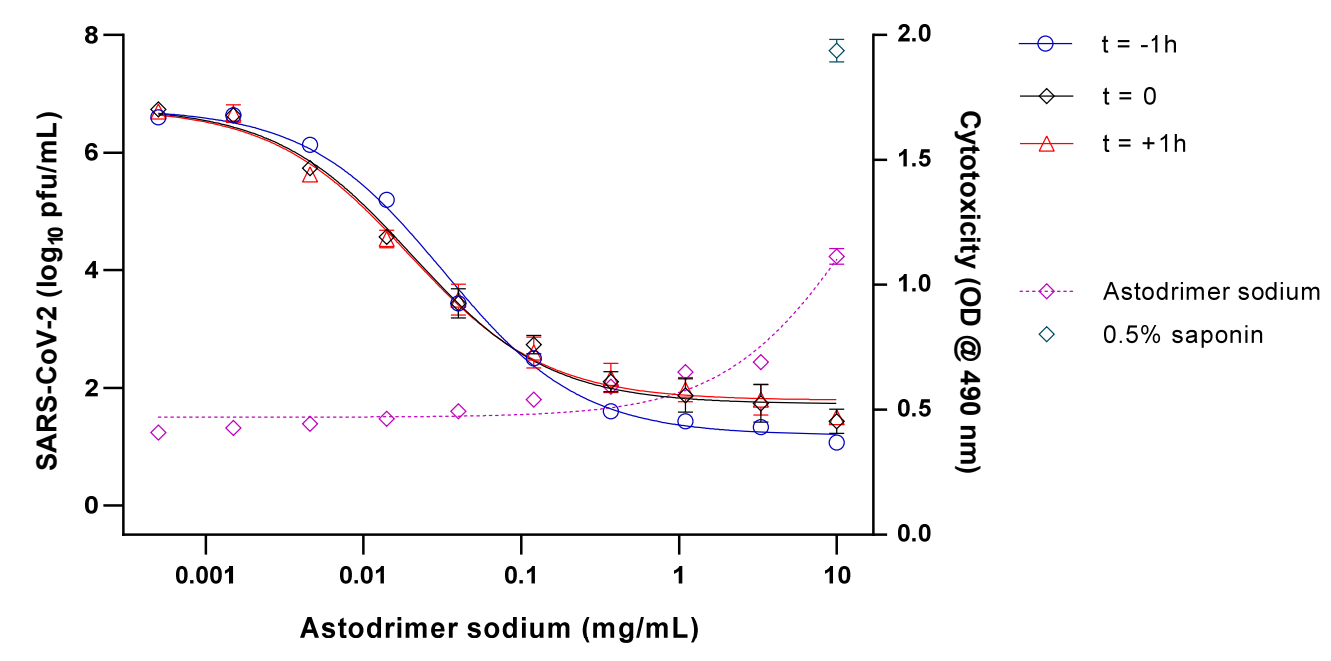

407

408 Fig. 2

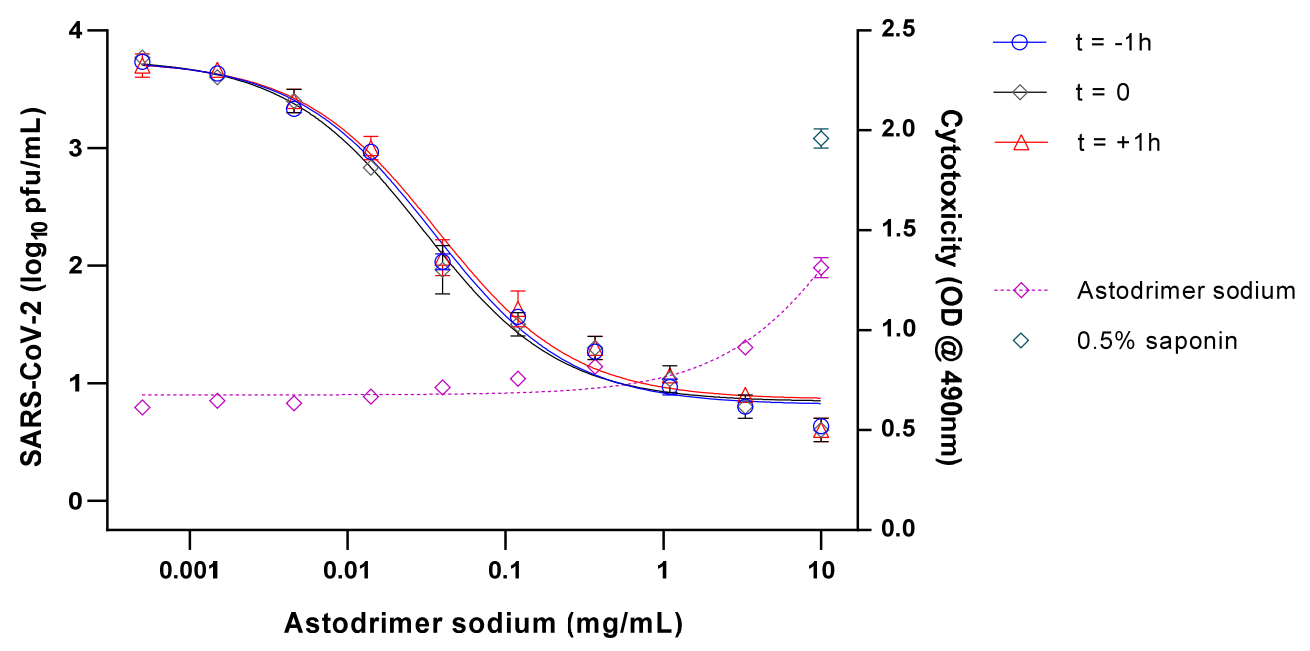

409 
$411 \quad$ Fig 3.

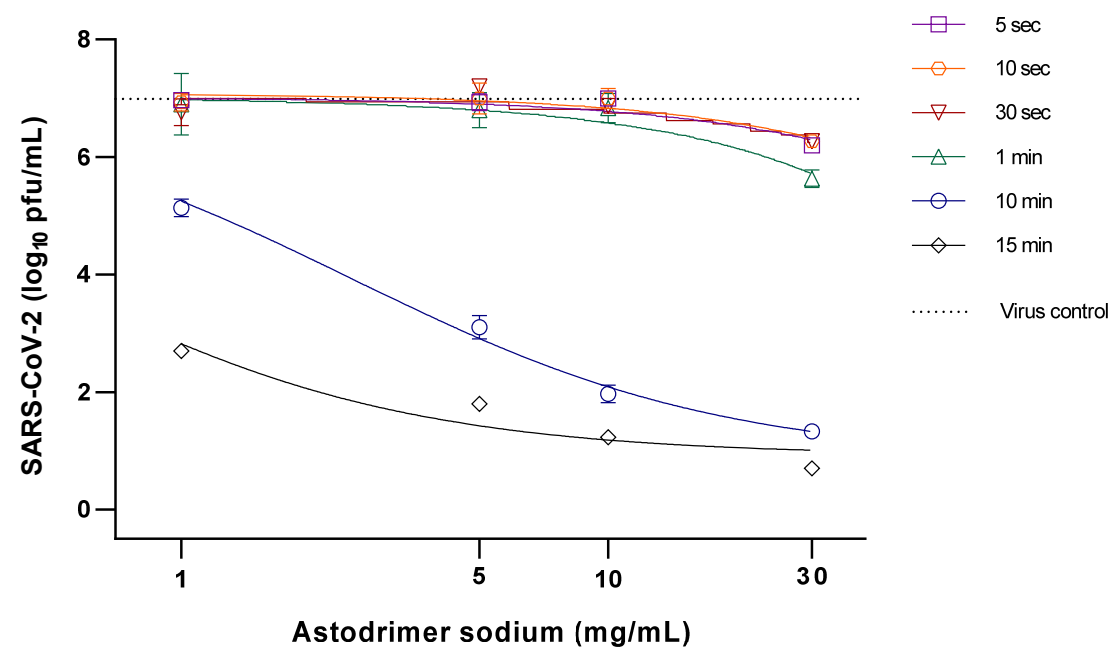

412

$413 \quad$ Fig 4.

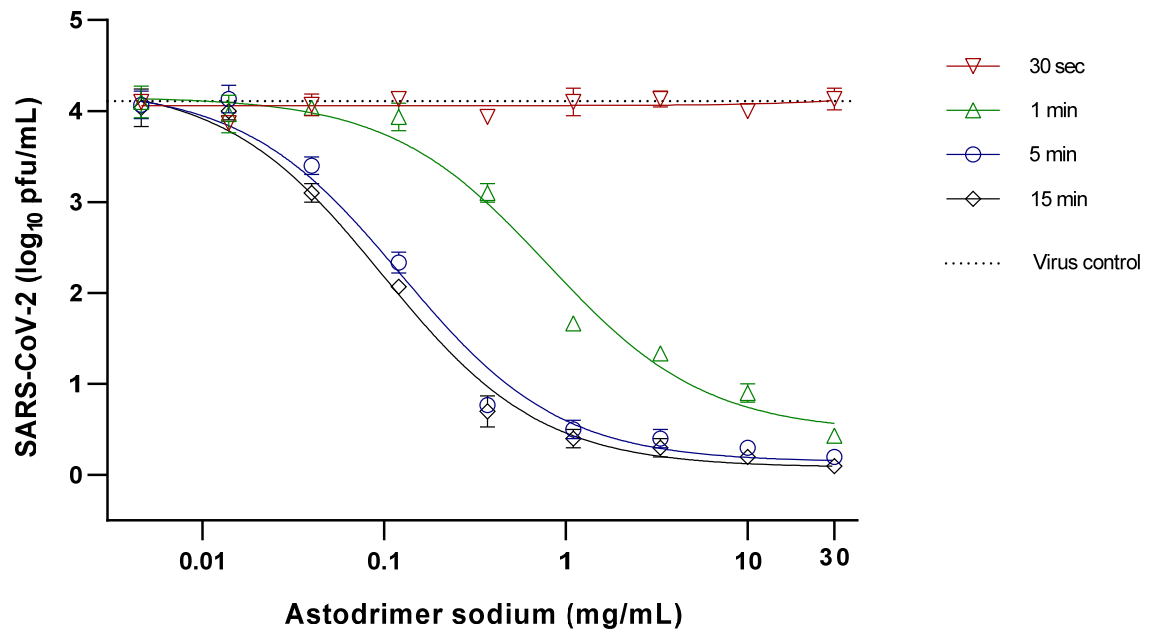

414 
$416 \quad$ Fig 5.

$417 \quad$ A

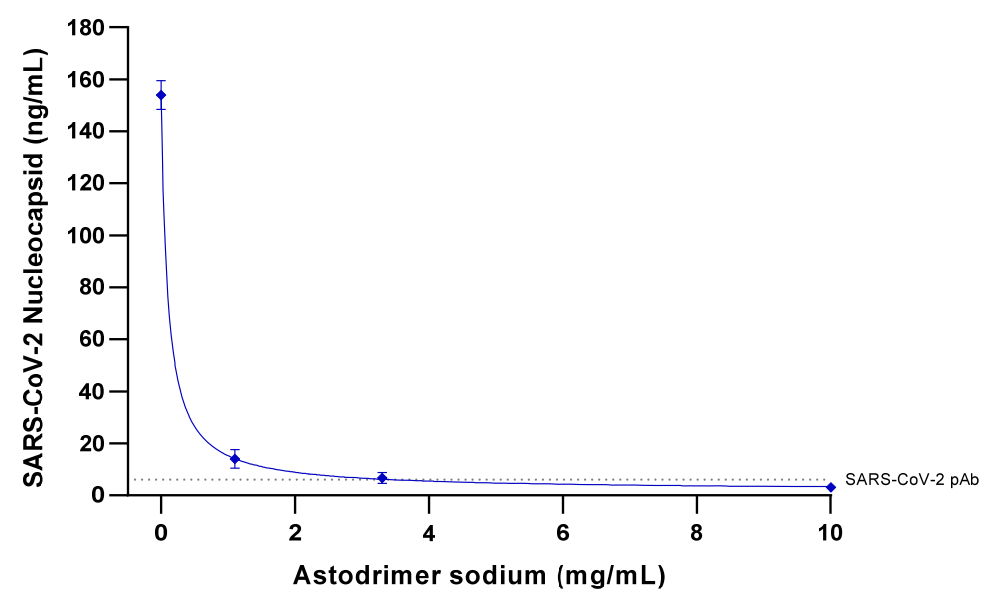

418

419 B

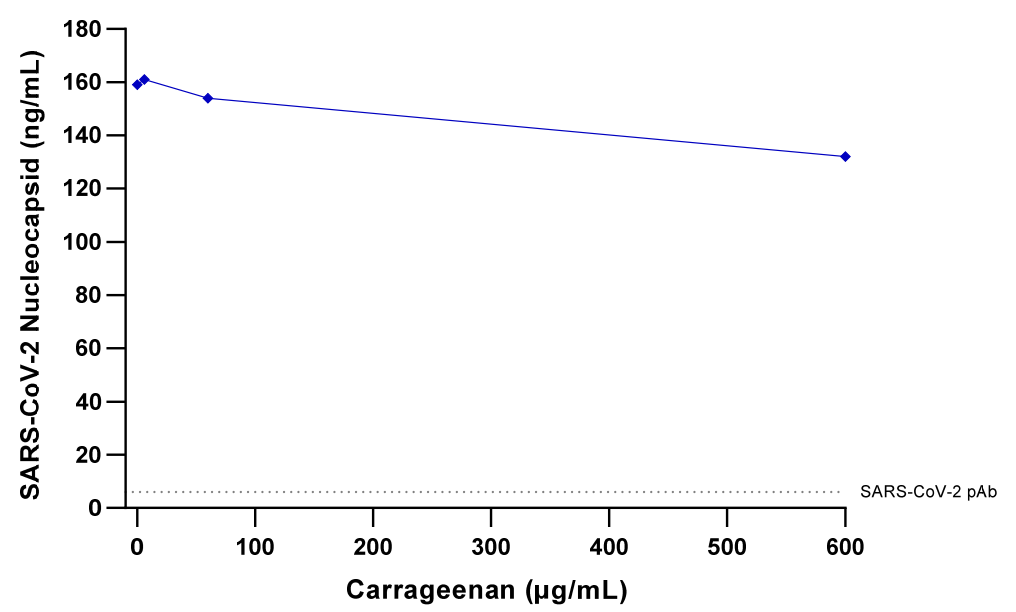

420

421

422 


\begin{tabular}{|c|c|c|c|}
\hline ACE2 & angiotensin converting enzyme 2 & LLOD & lower limit of detection \\
\hline BSA & bovine serum albumin & MEM & minimal essential medium \\
\hline BV & bacterial vaginosis & MOI & multiplicity of infection \\
\hline \multirow[t]{2}{*}{$\mathrm{CC}_{50}$} & $50 \%$ cytotoxic concentration & MTT & methylthiazolyldiphenyl- \\
\hline & & & tetrazolium bromide \\
\hline COVID-19 & coronavirus disease 2019 & $\mathrm{NC}$ & not calculated \\
\hline $\mathrm{CPE}$ & cytopathic effect & OD & optical density \\
\hline $\mathrm{EC}_{50}$ & $50 \%$ effective concentration & $\mathrm{pfu}$ & plaque forming unit \\
\hline \multirow[t]{2}{*}{ ELISA } & enzyme-linked immunosorbent & $\mathrm{RBD}$ & receptor binding domain \\
\hline & assay & & \\
\hline FBS & fetal bovine serum & S protein & spike protein \\
\hline \multirow[t]{2}{*}{ HBEpC } & human bronchial epithelial & SARS-CoV & severe acute respiratory \\
\hline & primary cells & & syndrome coronavirus \\
\hline \multirow[t]{2}{*}{ HIV-1 } & human immunodeficiency virus & SARS-CoV-2 & severe acute respiratory \\
\hline & type 1 & & syndrome coronavirus 2 \\
\hline HPV & human papillomavirus & SD & standard deviation \\
\hline \multirow[t]{2}{*}{ HRSV } & human respiratory syncytial virus & SHIV & simian-human \\
\hline & & & immunodeficiency virus \\
\hline HS & heparan sulfate proteoglycan & SI & selectivity index \\
\hline HSV & herpes simplex virus & $\mathrm{TCID}_{50}$ & $\begin{array}{l}\text { median tissue culture infective } \\
\text { dose }\end{array}$ \\
\hline HTEpC & $\begin{array}{l}\text { human tracheal epithelial primary } \\
\text { cells }\end{array}$ & TOA & time of addition \\
\hline
\end{tabular}




\begin{tabular}{|llll|}
\hline ITS & insulin-transferrin-selenium & TPCK & L-(tosylamido-2-phenyl) ethyl \\
& & & chloromethyl ketone \\
LDH & lactate dehydrogenase & UPLC & ultra-high-performance liquid \\
& & & chromatography \\
& &
\end{tabular}

\section{Acknowledgments}

426 The authors were fully responsible for the content, editorial decisions, and opinions expressed in

427 the current article. The authors would like to acknowledge 360Biolabs Pty Ltd (Melbourne,

428 Australia) for the conduct of the CPE assays and Scripps Research Institute for the conduct of the

429 antiviral and virucidal assays. The authors would also like to thank the Peter Doherty Institute for

430 Infection and Immunity (Melbourne, Australia) for the gift to 360Biolabs of SARS-CoV-2

431 hCoV-19/Australia/VIC01/2020 used in these studies.

432 Funding

433 The research was funded by Starpharma Pty Ltd, which was responsible for study design,

434 interpretation of data, writing the manuscript and decision to submit the article for publication.

\section{References}

436 Bernstein, D.I., Stanberry, L.R., Sacks, S., Ayisi, N.K., Gong, Y.H., Ireland, J., Mumper, R.J.,

437 Holan, G., Matthews, B, McCarthy, T., Bourne, N., 2003. Evaluations of unformulated and

438 formulated dendrimer-based microbicide candidates in mouse and guinea pig models of

439 genital herpes. Antimicrob. Agents Chemother. 47(12), 3784-3788.

440 https://doi.org/10.1128/aac.47.12.3784-3788.2003 
441 Bansal, S., Jonsson, C.B., Taylor, S.L., Figueroa, J.M., Vanesa, A.D., Palacios, C., Vega, J.C.,

442

443

444

445

446

447

448

449

450

451

452

453

454

455

456

457

458

459

460

461 2020. Iota-carrageenan and xylitol inhibit SARS-CoV-2 in cell culture. bioRxiv 2020.08.19.225854. https://doi.org/10.1101/2020.08.19.225854

Chavoustie, S.E., Carter, B.A., Waldbaum, A.S., Donders, G.G.G., Peters, K.H., Schwebke, J.R., Paull, J.R.A, Price, C.F., Castellarnau, A., McCloud, P., Kinghorn, G.R., 2020. Two phase 3, double-blinded, placebo-controlled studies of the efficacy and safety of Astodrimer 1\% Gel for the treatment of bacterial vaginosis. Eur. J. Obstet. Gynecol. Reprod. Biol. 245, 1318. https://doi.org/10.1016/j.ejogrb.2019.11.032

Chen, M.Y., Millwood, I.Y., Wand, H., Poynten, M, Law, M., Kaldor, J.M., Wesselingh, S., Price, C.F., Clark, L.J., Paull, J.R., Fairley, C.K., 2009. A randomized controlled trial of the safety of candidate microbicide SPL7013 gel when applied to the penis. J. Acquir. Immune Defic. Syndr. 50(4), 375-380. https://doi.org/10.1097/QAI.0b013e318198a7e6

Connell, B.J., Lortat-Jacob, H., 2013. Human immunodeficiency virus and heparan sulfate: from attachment to entry inhibition. Frontiers Immunol. 4, 385. https://doi.org/10.3389/fimmu.2013.00385

Ghosh, T., Chattopadhyay, K., Marschall, M., Karmakar, P., Mandal, P., Ray, B., 2009. Focus on antivirally active sulfated polysaccharides: from structure-activity analysis to clinical evaluation. Glycobiology 19(1), 2-15. https://doi.org/10.1093/glycob/cwn092

Gong, E., Matthews, B., McCarthy, T., Chu, J., Holan, G., Raff, J., Sacks, S., 2005. Evaluation of dendrimer SPL7013, a lead microbicide candidate against herpes simplex virus. Antiviral Res. 68(3), 139-146. https://doi.org/10.1016/j.antiviral.2005.08.004 
462 Hoffmann, M., Kleine-Weber, H., Pöhlmann, S., 2020a. A multibasic cleavage site in the spike 463 protein of SARS-CoV-2 is essential for infection of human lung cells. Molecular Cell 464 78(4), 779-784.e5. https://doi.org/10.1016/j.molcel.2020.04.022

465

466

467

468

469

470

471

472

473

474

475

476

477

478

479

480

481

482

483

484

Hoffmann, M., Kleine-Weber, H., Schroeder, S., Krüger, N., Herrler, T., Erichsen, S., Schiergens, T.S., Herrler, G., Wu, N.H., Nitsche, A., Müller, M.A., Drosten, C., Pöhlmann, S., 2020b. SARS-CoV-2 cell entry depends on ACE2 and TMPRSS2 and is blocked by a clinically proven protease inhibitor. Cell 181(2), 271-280.e8. https://doi.org/10.1016/j.cell.2020.02.052

Hou, Y.J., Okuda, K., Edwards, C.E., et al. 2020. SARS-CoV-2 reverse genetics reveals a variable infection gradient in the respiratory tract. Cell 182(2), 429-446.e14. https://doi.org/10.1016/j.cell.2020.05.042

Jiang, Y.H., Emau, P., Cairns, S., Flanary, L., Morton, W.R., McCarthy, T., Tsai, C.C., 2005. SPL7013 gel as a topical microbicide for prevention of vaginal transmission of SHIV $89.6 \mathrm{P}$ in macaques. AIDS Res. Hum. Retroviruses 21(3), 207-213. https://doi.org/10.1089/aid.2005.21.207

Korber, B., Fischer, W.M., Gnanakaran, S., Yoon, H., Theiler, J., Abfalterer, W., Foley, B., Giorgi, E.E., Bhattacharya, T., Parker, M.D., Partridge, D.G., Evans, C.M., de Silva, T.I., LaBranche, C.C., Montefiori, D.C., 2020. Spike mutation pipeline reveals the emergence of a more transmissible form of SARS-CoV-2. bioRxiv. https://doi.org/10.1101/2020.04.29.069054

Lackman-Smith, C., Osterling, C., Luckenbaugh, K., Mankowski, M., Snyder, B., Lewis, G., Paull, J., Profy, A., Ptak, R.G., Buckheit Jr., R.W., Watson, K.M., Cummins Jr., J.E., Sanders-Beer, B.E., 2008. Development of a comprehensive human immunodeficiency 
485

486

487

488

489

490

491

492

493

494

495

496

497

498

499

500

501

502

503

504

505

506

virus type-1 screening algorithm for discovery and preclinical testing of topical

microbicides. Antimicrob. Agents Chemother. 52(5), 1768-1781.

https://doi.org/10.1128/AAC.01328-07

Lang, J., Yang, N., Deng, J., Liu, K., Yang, P., Zhang, G., Jiang, C., 2011. Inhibition of SARS pseudovirus cell entry by lactoferrin binding to heparan sulfate proteoglycans. PLoS ONE 6(8), e23710. https://doi.org/10.1371/journal.pone.0023710

Liu, L., Chopra, P., Li, X., Wolfert, M.A., Tompkins, S.M., Boons, G.J., 2020. SARS-CoV-2 spike protein binds heparan sulfate in a length- and sequence-dependent manner. bioRxiv. https://doi.org/10.1101/2020.05.10.087288

McCarthy, T.D., Karellas, P., Henderson, S.A., Giannis, M., O'Keefe, D.F., Heery, G., Paull, J.R.A., Matthews, B.R., Holan, G., 2005. Dendrimers as drugs: discovery and preclinical and clinical development of dendrimer microbicides for HIV and STI prevention. Mol. Pharm. 2(4), 312-318. https://doi.org/10.1021/mp050023q

McGowan, I., Gomez, K., Bruder, K., Febo, I., Chen, B.A., Richardson, B.A., Husnik, M., Livant, E., Price, C., Jacobson, C., 2011. Phase 1 randomized trial of the vaginal safety and acceptability of SPL7013 gel (VivaGel $\left.{ }^{\circledR}\right)$ in sexually active young women (MTN-004). AIDS 25(8), 1057-1064. https://doi.org/10.1097/QAD.0b013e328346bd3e

Milewska, A., Zarebski, M., Nowak, P., Stozek, K., Potempa, J., Pyrc, K., 2014. Human coronavirus NL63 utilizes heparan sulfate proteoglycans for attachment to target cells. J. Virol. 88(22), 13221-13230. https://doi.org/10.1128/JVI.02078-14

Mycroft-West, C., Su, D., Elli, S., Li, Y., Guimond, S., Miller, G., Turnbull, J., Yates, E., Guerrini, M., Fernig, D., Lima, M., Skidmore, M., 2020a. The 2019 coronavirus (SARS- 
$\mathrm{CoV}-2$ ) surface protein (spike) S1 receptor binding domain undergoes conformational change upon heparin binding. bioRxiv. https://doi.org/10.1101/2020.02.29.971093

Mycroft-West, C.J., Su, D., Li, Y., Guimond, S., Rudd, T.R., Elli, S., Miller, G., Nunes, Q.M., Procter, P., Bisio, A., Forsyth, N.R., Turnbull, J.E., Guerrini, M., Fernig, D., Yates, E.A., Lima, M.A., Skidmore, M.A., 2020b. SARS CoV-2 spike S1 receptor binding domain undergoes conformational change upon interaction with low molecular weight heparins.

Mycroft-West, C.J., Su, D., Pagani, I., Rudd, T.R., Elli, S., Guimond, S., Miller, G., Meneghetti, M.C.Z., Nader, H.B., Li, Y., Nunes, Q.M., Procter, P., Mancini, N., Clementi, M., Forsyth, N.R., Turnbull, J.E., Guerrini, M., Fernig, D., Vicenzi, E., Yates, E.A., Lima, M.A., bioRxiv. https://doi.org/10.1101/2020.04.29.068486

520 Skidmore, M.A., 2020c. Heparin inhibits cellular invasion of SARS-CoV-2: structural dependence on the interaction of the surface protein (spike) S1 receptor binding domain with heparin. bioRxiv 2020.2004.2028.066761. https://doi.org/10.1101/2020.04.28.066761

O’Loughlin, J., Millwood, I.Y., McDonald, H.M., Price, C.F., Kaldor, J.M., Paull, J.R.A., 2010.

524 Ogando, N.S., Dalebout, T.J., Zevenhoven-Dobbe, J.C., Limpens, R.W.A.L., van der Meer, Y., Caly, L., Druce, J., de Vries, J.J.C., Kikkert, M., Bárcena, M., Sidorov, I., Snijder, J., 2020. SARS-coronavirus-2 replication in Vero E6 cells: replication kinetics, rapid adaption and cytopathology. J. General Virol. 10.1099/jgv.0.001453. Advance online publication. https://doi.org/10.1099/jgv.0.001453 
529 Pauwels, R., Balzarini, J., Baba, M., Snoeck, R., Schols, D., Herdewijn, P., Desmyter, J., De

530 Clercq, E., 1988. Rapid and automated tetrazolium-based colorimetric assay for the 531 detection of anti-HIV compounds. J. Virol. Methods 20(4), 309-321.

$532 \quad$ https://doi.org/10.1016/0166-0934(88)90134-6

533 Pizzorno, A., Padey, B., Dubois, J., Julien, T., Traversier, A., Dulière, V., Brun, P., Lina, B., 534 Rosa-Calatrava, M., Terrier, O., 2020. In vitro evaluation of antiviral activity of single and 535 combined repurposable drugs against SARS-CoV-2. Antiviral Res. 104878. Advance online publication. https://doi.org/10.1016/j.antiviral.2020.104878

537 Qiao, B., Olvera de la Cruz, M., 2020. The distal polybasic cleavage sites of SARS-CoV-2 spike protein enhance spike protein-ACE2 binding. bioRxiv June 10. https://doi.org/10.1101/2020.06.09.142877

540 Sarrazin, S., Lamanna, W.C., Esko, J.D., 2011. Heparan sulfate proteoglycans. Cold Spring Harb. Perspect. Biol. 3(7), a004952. https://doi.org/10.1101/cshperspect.a004952

542 Schwebke, J., Carter, B., Waldbaum, A., Price, C., Castellarnau, A., Paull, J., McCloud, P., Kinghorn, G., 2021. A phase 3, randomized, controlled trial of Astodrimer 1\% Gel for preventing recurrent bacterial vaginosis. Eur. J. Obstet. Gynecol. Reprod. Biol. X 10,

546 Sungnak, W., Huang, N., Bécavin, C., Berg, M., Queen, R., Litvinukova, M., Talavera-López, C., Maatz, H., Reichart, D., Sampaziotis, F., Worlock, K.B., Yoshida, M., Barnes, J.L., 2020. SARS-CoV-2 entry factors are highly expressed in nasal epithelial cells together with innate immune genes. Nat. Med. 26(5), 681-687. https://doi.org/10.1038/s41591-0200868-6 
551 Telwatte, S., Moore, K., Johnson, A., Tyssen, D., Sterjovski, J., Aldunate, M., Gorry, P.R.,

552 Ramsland, P.A., Lewis, G.R., Paull, J.R.A., Sonza, S., Tachedjian, G., 2011. Virucidal 553 activity of the dendrimer microbicide SPL7013 against HIV-1. Antiviral Res. 90(3), 195554 199. https://doi.org/10.1016/j.antiviral.2011.03.186

555 Tyssen, D., Henderson, S.A., Johnson, A., Sterjovski, J, Moore, K., La, J., Zanin, M., Sonza, S., 556 Karellas, P., Giannis, M.P., Krippner, G., Wesselingh, S., McCarthy, T., Gorry, P.R., 557 Ramsland, P.A., Cone, R., Paull, J.R.A., Lewis, G.R., Tachedjian, G., 2010. Structure 558 activity relationship of dendrimer microbicides with dual action antiviral activity. PLoS 559 ONE 5(8), e12309. https://doi.org/10.1371/journal.pone.0012309

560 van den Worm, S.H., Eriksson, K.K., Zevenhoven, J.C., Weber, F., Zust, R., Kuri, T., Dijkman, 561 R., Chang, G., Siddell, S.G., Snijder, E., Thiel, V., Davidson, A.D., 2012. Reverse genetics 562 563 of SARS-related coronavirus using vaccinia virus-based recombination. PLoS ONE 7(3):e32857. https://doi.org/10.1371/journal.pone.0032857

564 Waldbaum, A.S., Schwebke, J.R., Paull, J.R.A., Price, C.F., Edmondson, S.R., Castellarnau, A., 565 McCloud, P., Kinghorn, G.R., 2020. A phase 2, double-blind, multicenter, randomized, placebo-controlled, dose-ranging study of the efficacy and safety of Astodrimer Gel for the treatment of bacterial vaginosis. PLoS ONE 15(5), e0232394.

Walls, A.C., Park, Y.J., Tortorici, M.A., Wall, A., McGuire, A.T., Veesler, D., 2020. Structure, 570 function and antigenicity of the SARS-CoV-2 spike glycoprotein. Cell 181(2), 281-292.e6 https://doi.org/10.1016/j.cell.2020.02.058 
572 Wang, M., Cao, R., Zhang, L., Yang, X., Liu, J., Xu, M/., Shi, Z., Hu, Z., Zhong, W., Xiao, G., 573 2020. Remdesivir and chloroquine effectively inhibit the recently emerged novel 574 coronavirus (2019-nCoV) in vitro. Cell Res. 30(3), 269-271.

575 https://doi.org/10.1038/s41422-020-0282-0

576 Wrapp, D., Wang, N., Corbett, K.S., Goldsmith, J.A., Hsieh, C.L., Abiona, O., Graham, B.S., 577 McLellan, J.S., 2020. Cryo-EM structure of the 2019-nCoV spike in the prefusion 578 conformation. Science 367(6483), 1260-1263. https://doi.org/10.1126/science.abb2507

579 Yuan, M., Wu, N.C., Zhu, X., Lee, C.C.D., So, R.T.Y., Lv, H., Mok, C.K.P., Wilson, I.A., 2020. 580 A highly conserved cryptic epitope in the receptor binding domains of SARS-CoV-2 and 581 SARS-CoV. Science 368(6491), 630-633. https://doi.org/10.1126/science.abb7269 
Figures

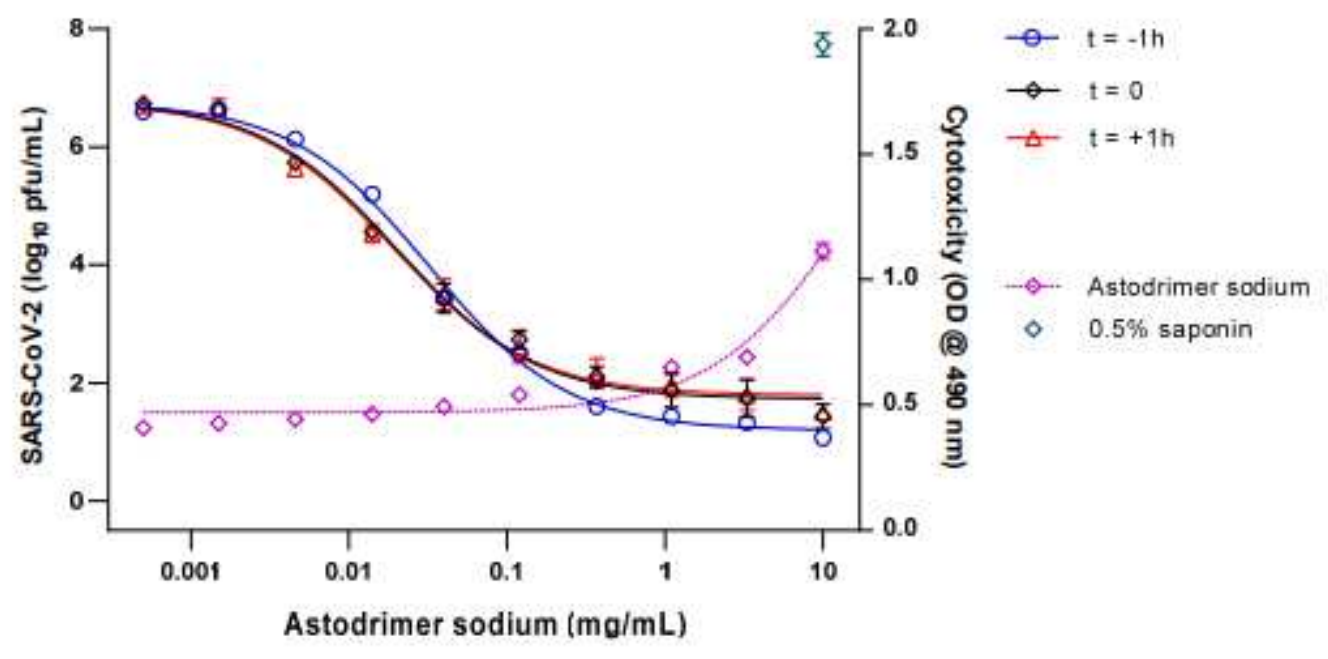

Figure 1

Dose-response and cytotoxicity analysis of SARS-CoV-2 (2019-nCoV/USA WA1/2020) antiviral activity of astodrimer sodium in Vero E6 cells as measured by infectious virus release (Log10 pfu/mL) on Day 4 post-infection

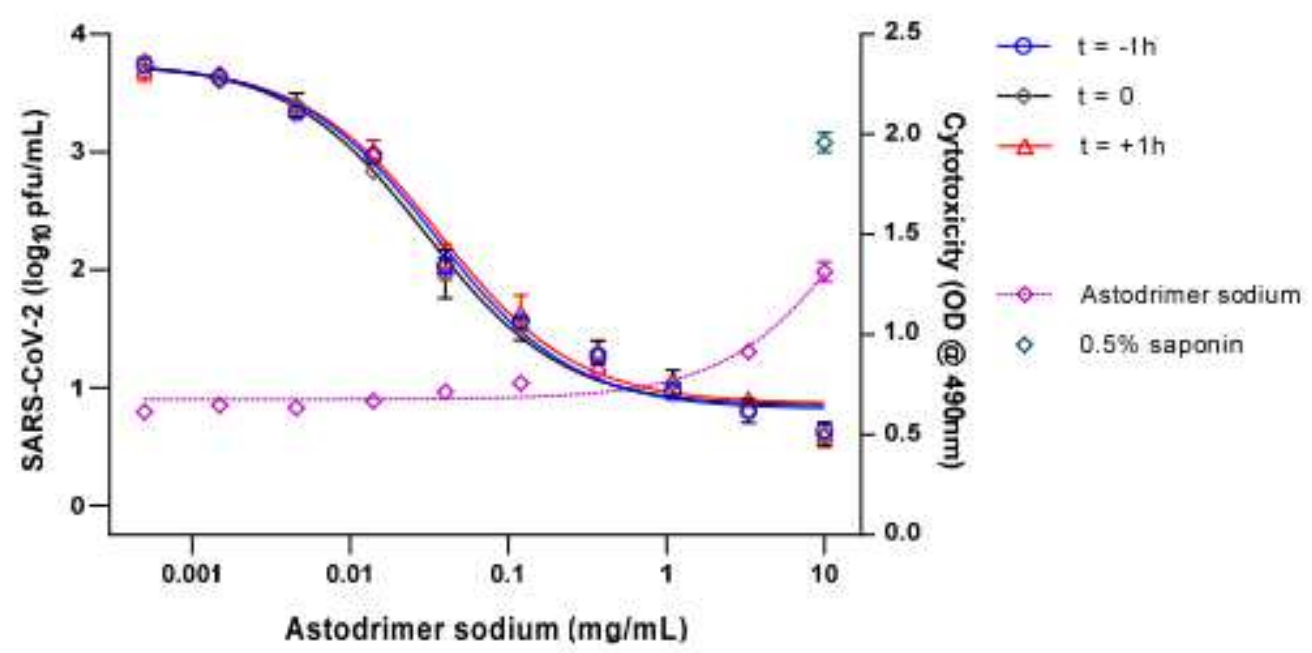

Figure 2

Dose-response and cytotoxicity analysis of SARS-CoV-2 (2019-nCoV/USA WA1/2020) antiviral activity of astodrimer sodium in Calu-3 cells as measured by infectious virus release (Log10 pfu/mL) on Day 4 postinfection 


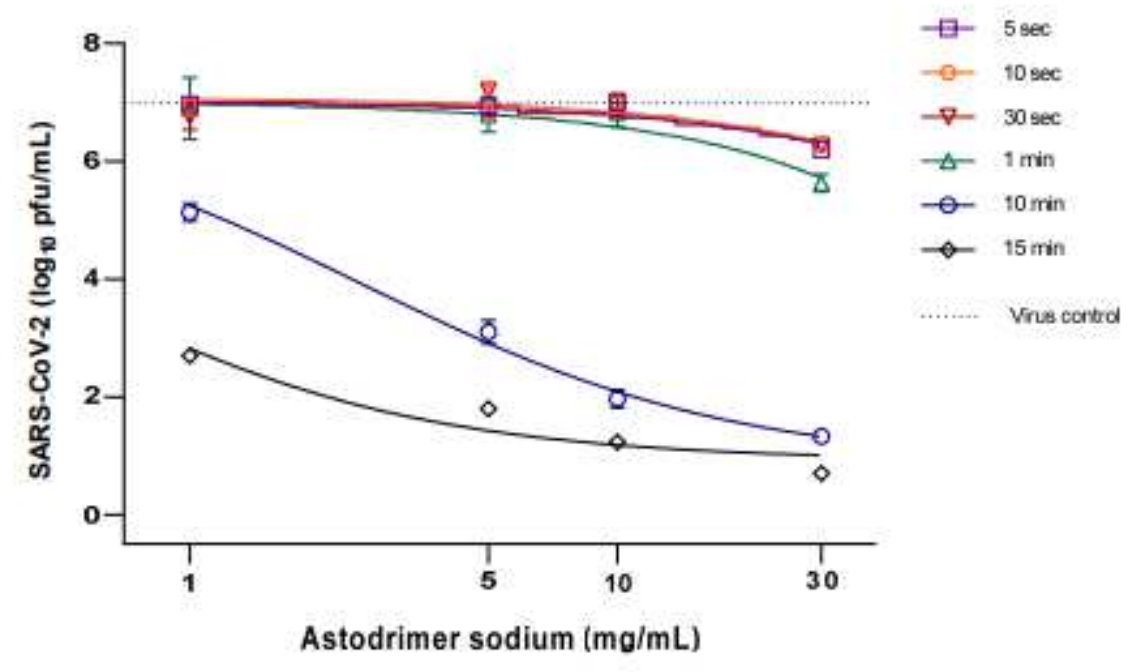

Figure 3

Virucidal efficacy of astodrimer sodium against SARS-CoV-2 (2019-nCoV/USA WA1/2020) measured by a reduction in mean infectious virus (Log10 pfu/mL), at 96 hours post-infection in Vero E6 cells

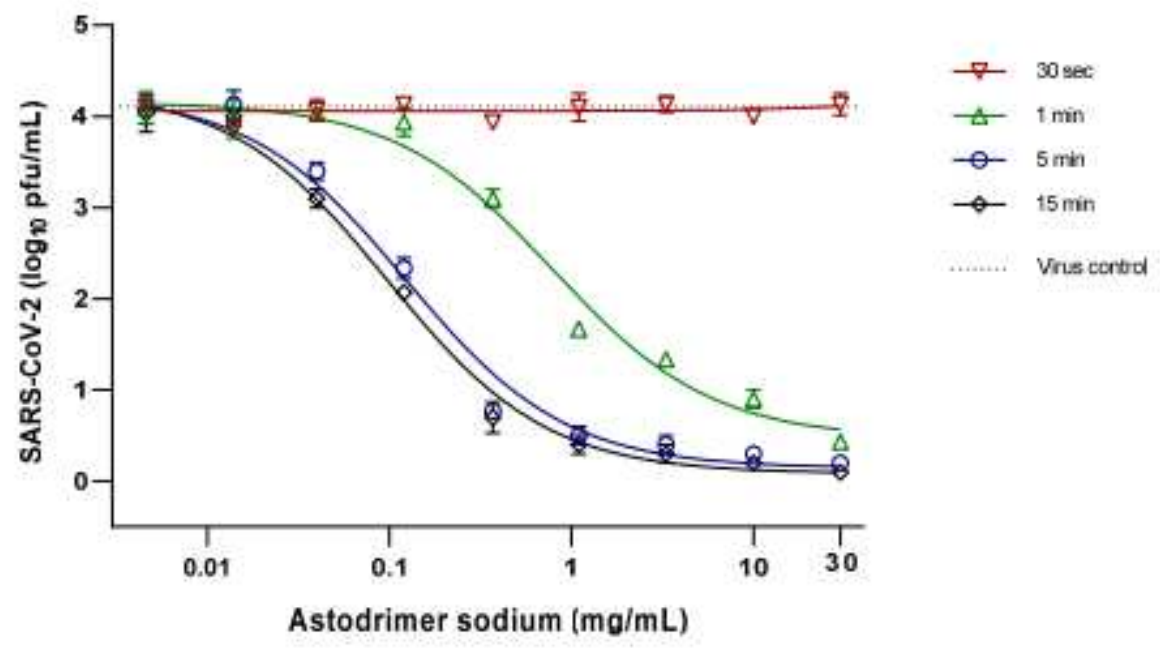

Figure 4

Virucidal efficacy of astodrimer sodium against SARS-CoV-2 (2019-nCoV/USA WA1/2020) measured by a reduction in mean infectious virus (Log10 pfu/mL), at 16 hours post-infection in Vero E6 cells 
A

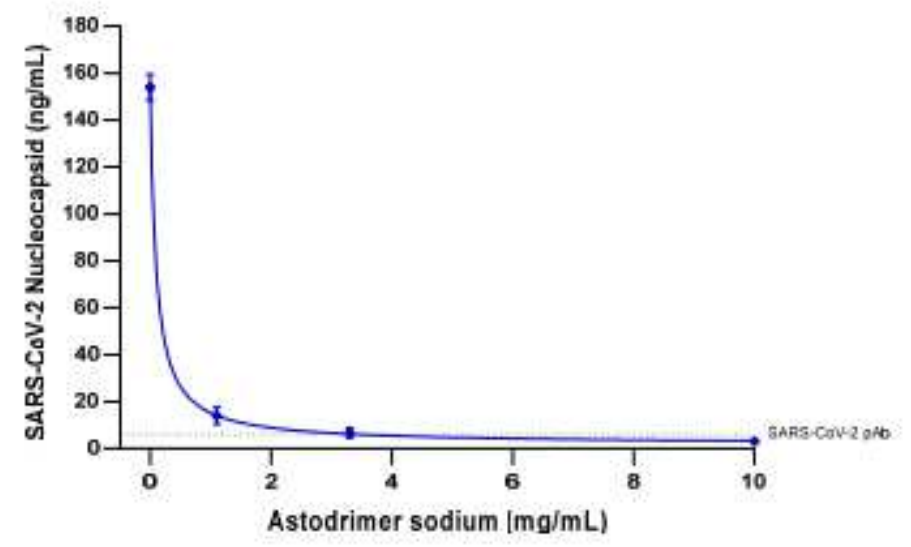

B

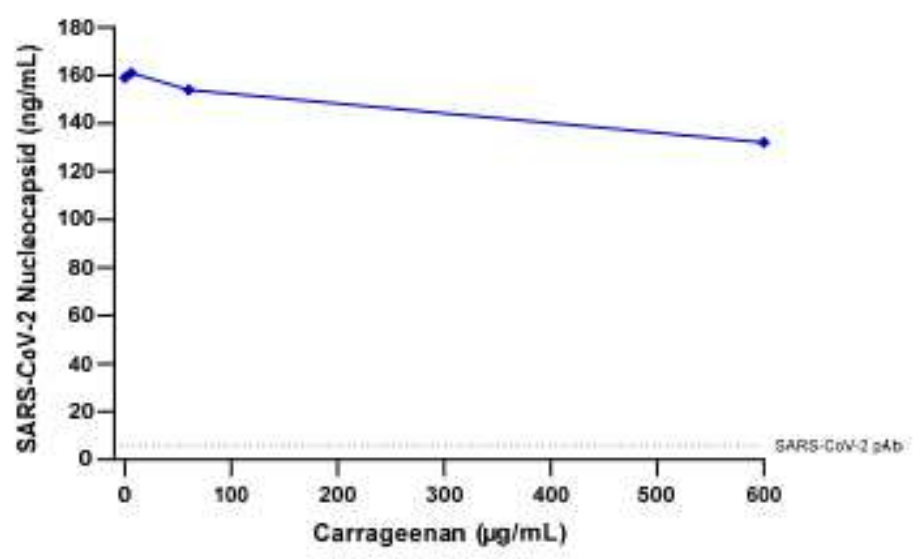

Figure 5

Antiviral efficacy of astodrimer sodium and iota-carrageenan against SARS CoV-2 (2019-nCoV/USAWA1/2020) measured by a reduction in nucleocapsid $(\mathrm{ng} / \mathrm{mL})$, at Day 4 post-infection in human bronchial epithelial primary cells (HBEpC) 